\title{
Organic Extracts
}

\section{From JOIDES Cores}

Off Northeastern Florida

GEOLOGIGAL SURVEY PROFESSIONAL PAPER 581-G

Prepared in cooperation with the Woods Hole

Oceanographic Institution and the Joint

Oceanographic Institutions' Deep Earth

Sampling Program

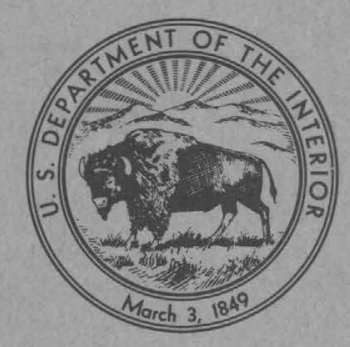





\section{Organic Extracts \\ From JOIDES Cores \\ Off Northeastern Florida}

By E. E. BRAY and E. D. EVANS

DRILLING ON THE CONTINENTAL MARGIN OFF FLORIDA

GEOLOGICAL SURVEY PROFESIONAL PAPER 581-C

Prepared in cooperation with the Woods Hole

Oceanographic Institution and the Joint

Oceanographic Institutions' Deep Earth

Sampling Program

A study of organic extracts from deep core

samples from the continental shelf, the

Florida-Hatteras Slope, and the Blake Plateau

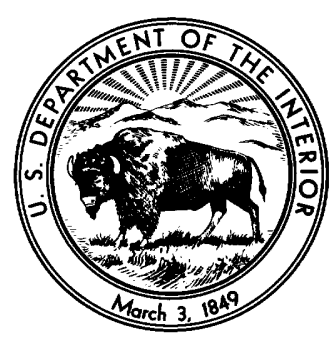

UNITED STATES GOVERNMENT PRINTING OFFICE, WASHINGTON : 1969 


\section{UNITED STATES DEPARTMENT OF THE INTERIOR \\ WALTER J. HIGKEL, Secretary \\ GEOLOGIGAL SURVEY \\ William T. Pecora, Director}

For sale by the Superintendent of Documents, U.S. Government Printing Office

.Washington, D.C. 20402 - Price 25 cents (paper cover) 


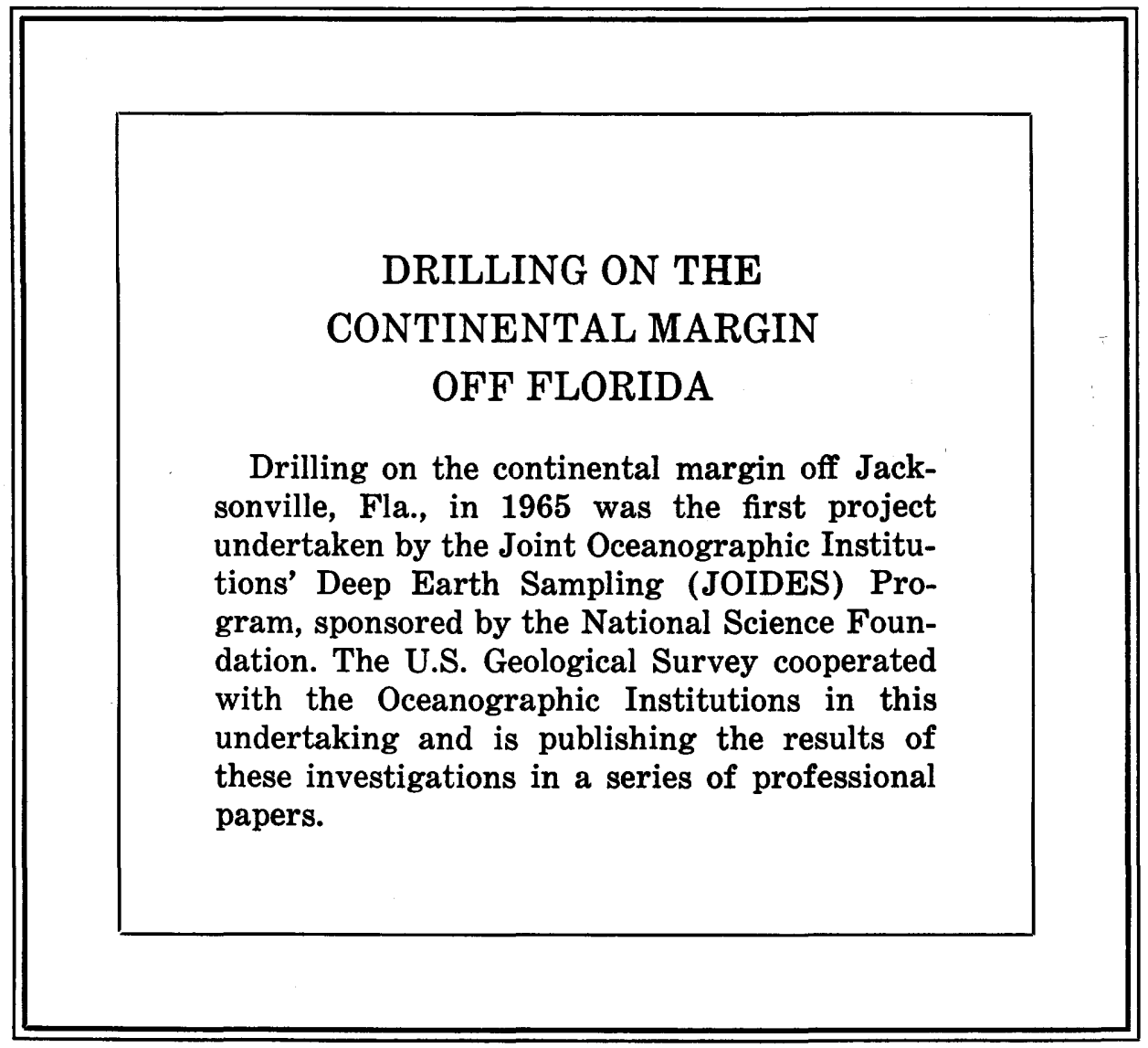




\section{CONTENTS}

Abstract
Introduction
Acknowledgments
Analyses of samples
Discussion
Summary and conclusions
References

\section{ILLUSTRATION}

FIgURE 1. Index map for JOIDES drill sites $\quad$ Page

\section{TABLES}

TABLE 1. Identification of samples from JOIDES core holes

2. Analytical data on organic extracts in samples from JOIDES core holes

3. Organic carbon, hydrocarbon, calcium carbonate, and EOM contents in samples from JOIDES core holes _.......- 
$$
\text { . }
$$ 


\title{
DRILLING ON THE CONTINENTAL MARGIN OFF FLORIDA
}

\section{ORGANIC EXTRACTS FROM \\ JOIDES CORES OFF NORTHEASTERN FLORIDA}

\author{
By E. E. BraY ${ }^{1}$ and E. D. Evans ${ }^{1}$
}

\begin{abstract}
Extracts of samples from cores of Tertiary strata at six sites off the Atlantic coast of northern Florida and across the Blake Plateau contained very meager quantities of hydrocarbons and other soluble organic material.

Eleven samples forming a group with the least carbonate content from the shelf and continental slope were available for hydrocarbon analyses. In five of these samples from depths less than 25 meters below the ocean floor, the smaller molecular sizes, ranging from $\mathrm{C}_{12}$ to $\mathrm{C}_{20}$, averaged 22.1 percent of the saturated hydrocarbons $\left(\mathrm{C}_{12}-\mathrm{C}_{30}\right)$, whereas in the remaining six samples from greater depths, this fraction averaged 36.5 percent.
\end{abstract}

\section{INTRODUCTION}

A suite of samples from cores beginning at the ocean floor and extending to great depths is potentially valuable for observing chemical changes in organic material within sediments as a function of burial and time at crustal temperatures. An opportunity to acquire a suite of these samples was afforded early in 1965 by the Joint Oceanographic Institutions' Deep Earth Sampling (JOIDES) Program (1965).

Six holes were drilled across the continental shelf and slope off the Atlantic coast of northern Florida and across the Blake Plateau at the positions indicated in figure 1 and table 1.

Water depths at the drill sites ranged from 25 to 1,036 meters, and penetrations into the bottom sediments ranged from 178 to 320 meters. Positions were determined by loran $\mathrm{A}$. Two of three core holes drilled on the Blake Plateau penetrated into Paleocene strata, and thus sediments from most of the Cenozoic strata were sampled; the third core hole (J-3) penetrated strata of early Eocene age. On the continental shelf and slope, Cenozoic sediments were thicker, and the maximum penetration was into strata of middle Eocene age.

The core samples, preserved by freezing at the collection site, were received late in 1965. Samples

1 Mobil Research and Development Corp., P.O. Box 900, Dallas, Tex. 75221. were very small, averaging about 40 grams of dry sediment; but in spite of the sample sizes, some useful information about the hydrocarbons and lipids was retrieved and is herein placed on record.

\section{ACKNOWLEDGMENTS}

We wish to thank R. H. Meade, John M. Hunt, and Vernon E. Swanson for their constructive suggestions and K. O. Emery and his associates at the Woods Hole Oceanographic Institution, whose efforts and counsel were important factors in the initiation and execution of this study. We also thank the National Science Foundation for its grant to Lamont Geological Observatory, on behalf of JOIDES, to finance the drilling of the six offshore holes, and we are indebted to the Mobil Research and Development Corp. for providing the support for analyses of the samples and preparation of the report.

\section{ANALYSES OF SAMPLES}

An objective in studying the distribution of organic molecular species in sediments from near the ocean floor downward to great depths is to follow the transformation of organic material to hydrocarbons. In this particular set of very small samples, the $n$-paraffins were so sparse as to be beyond the reach of our analytical techniques. However, other parameters were examined which were within reach analytically. These parameters included concentrations of extractable organic material (EOM), concentrations of heavy hydrocarbons $\left(\mathrm{C}_{18+}\right)$ in the sediment, percent of heavy hydrocarbons in the EOM, and the amount of saturated hydrocarbons in the $\mathrm{C}_{12}-\mathrm{C}_{20}$ molecular size range relative to those in the total $\mathrm{C}_{12}-\mathrm{C}_{30}$ fraction. The analytical results for concentrations of heavy hydrocarbons $\left(\mathrm{C}_{18+}\right)$ in the sediment are approximately comparable to data in the literature (Baker, 1962; Gehman, 1962; Hunt, 1961; and Philippi, 1957). 


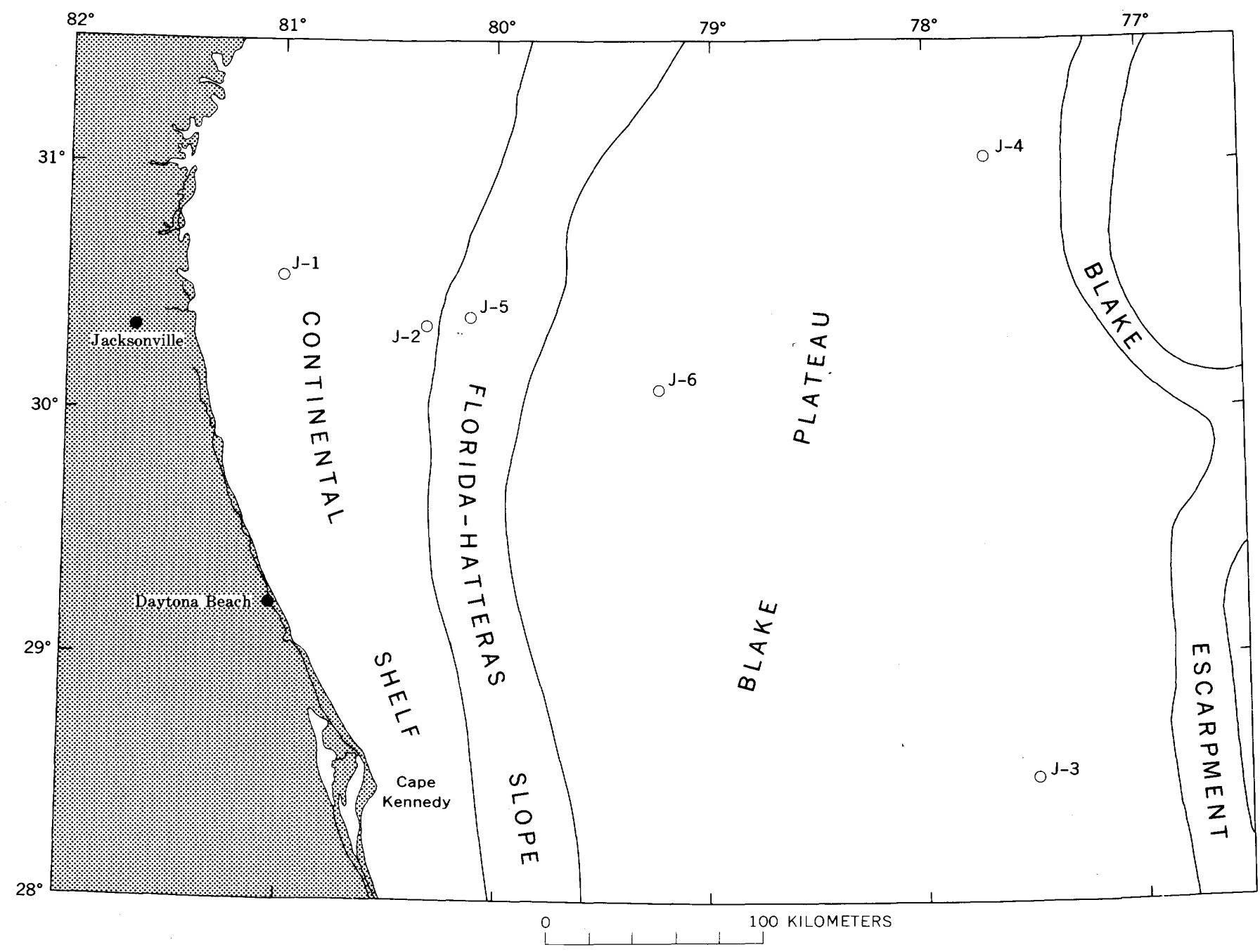

FIGURE 1.-JOIDES drill sites, Atlantic Ocean. (Modified from Joint Oceanographic Institutions' Deep Earth Sampling Program, 1965.)

The samples were air dried at $38^{\circ} \mathrm{C}$, pulverized to pass a 14-mesh sieve, and extracted by ball milling in the presence of a solvent for 4 hours to yield reproducible values of EOM. One or two milliliters of mixed solvent ( 10 parts benzene, 1 part methanol) per gram of dried sediment was used in the extraction process. Distilled water was then added to aggregate the pulverized sediment so that it could be separated from the solvent. The solvent was decanted and the insoluble solid material removed by filtering. A measured portion of the extract was stabilized by forced evaporation of the solvent at $40^{\circ} \mathrm{C}$. The amount of EOM was determined by weighing and also by dissolving the residue in $\mathrm{CS}_{2}$ for an infrared (IR) absorption spectrogram, from which measurement of the $\mathrm{C}-\mathrm{H}$ bond stretching fundamental (3.42 microns) provided an estimate of the amount of organic extract. A large discrepancy between the weighed amount of residue and the amount determined by IR absorption measurement provided a clue for the presence of elemental sulfur. In event of discrepancy, the residue was treated to remove sulfur.

The stabilized extract residues were dissolved and chromatographed on activated silica gel by using in sequence, as eluting agents, $n$-heptane, carbon tetrachloride, benzene, and methanol. The $n$-heptane fraction $(\mathrm{F}-1)$ contained the heavy saturated hydrocarbons $\left(\mathrm{C}_{18+}\right)$ which were present. The carbon tetrachloride fraction $(\mathrm{F}-2)$ and the benzene fraction $(F-3)$ were predominantly heavy aromatic hydrocarbons, though some oxygen-bearing impurities were present. The methanol fraction $(\mathrm{F}-4)$ was composed of asphaltic (nonhydrocarbon) compounds. The eluting solvents were removed by forced evaporation at $40^{\circ} \mathrm{C}$, and the amount of residue in each of the fractions was determined by weighing. The noneluted fraction remaining on the silica gel 
was determined by weight loss and designated as F-5. IR spectra were obtained for each of the chromatographic fractions dissolved in $\mathrm{CS}_{2}$ in order to characterize the material and observe the purity of the fractions. The solvents were carefully distilled to contain less than 0.2 microgram per milliliter of impurities that would be recovered with the sample and eluates. The silica gel was 100-200 mesh, grade 923, Davison Co. silica gel which was activated prior to use, at $425^{\circ} \mathrm{C}$ for 6 hours. The chromatographic columns ( $10 \mathrm{~mm}$ ID by $360 \mathrm{~mm}$ long) each contained 9 grams of the freshly activated silica gel. Column charges were adjusted to contain not more than 20 milligrams of asphaltic materials so as not to exceed the retention capacity of the silica gel.

The loss of saturated hydrocarbons in the $\mathrm{C}_{12}-\mathrm{C}_{20}$ molecular size range was avoided by use of a second method applied to a measured portion of the original extract. This portion of extract was concentrated to 10 milliliters to which 10 milliliters of $n$-heptane was added. The solution of extract and $n$-heptane was then concentrated to approximately 5 milliliters. During these concentration steps, the original benzene solvent had been largely removed, leaving the sample dissolved in the less volatile solvent, $n$-heptane. The saturated hydrocarbons were then isolated by adsorption chromatography. The separation was made using a 9-gram column of activated silica gel and eluting the saturated-hydrocarbon content of the sample with $n$-heptane. The effluent was then concentrated for gas chromatographic characterization.

Gas chromatographic analyses were made on a 10-foot column, one-eighth inch outside diameter, containing 4 percent silicone gum rubber (SE-30) on 60-80 mesh chromosorb W. Linear programming from $75^{\circ}$ to $300^{\circ} \mathrm{C}$ was used with hydrogen flame detection. Although the samples were too small to allow separation and measurement of $n$-paraffin distributions, molecular size distributions ranging from $\mathrm{C}_{12}$ to $\mathrm{C}_{30}$ in the total saturated hydrocarbons were estimated from the chromatograms. From summations of peak areas in the gas chromatographic data, the relative amounts of hydrocarbons were estimated in the $\mathrm{C}_{12}$ to $\mathrm{C}_{20}$ (low-boiling fraction) and $\mathrm{C}_{20}$ to $\mathrm{C}_{30}$ molecular size ranges. These analytical techniques did not quantitatively assay for hydrocarbons lighter than $\mathrm{C}_{12}$. Column "bleeding" interfered with determining molecular sizes larger than $\mathrm{C}_{30}$.

The samples analyzed are indentified in table 1 ; core-hole number, location, depth, geologic age, and lithologic description are given.

TABLE 1.-Identification of samples from JOIDES core holes

[Data from Schlee and Gerard, 1965]

\begin{tabular}{|c|c|c|}
\hline $\begin{array}{c}\text { Core } \\
\text { depth } \\
\text { (meters) }\end{array}$ & Geologic age & Sample description \\
\hline \multicolumn{3}{|c|}{ Core hole J-1 (lat $30^{\circ} 33^{\prime}$ N., long $81^{\circ} 00^{\prime}$ W.)-water depth, 25 meters } \\
\hline 0 & Post-Miocene_ & $\begin{array}{l}\text { Sand, fine- to medium-grained, well-sorted, shelly, unconsolidated; quartz, clear to cloudy; } \\
\text { pelecypod shells abundant; dark minerals scarce. }\end{array}$ \\
\hline 15.2 & -....do.. & $\begin{array}{l}\text { Sand, fine- to medium-grained, silty, quartz, calcareous, massive, unconsolidated; } \mathrm{H}_{2} \mathrm{~S} \\
\text { odor; foraminifers abundant. }\end{array}$ \\
\hline 22.8 & Late Miocene.. & Silt, coarse-grained, sandy, calcareous, quartz, phosphatic, compacted; $\mathrm{H}_{2} \mathrm{~S}$ odor. \\
\hline 30.5 & .....do.... & $\begin{array}{l}\text { Silt, quartz, micaceous, slightly calcareous, phosphatic, massive, plastic to compacted; } \\
\text { strong } \mathrm{H}_{2} \mathrm{~S} \text { odor. }\end{array}$ \\
\hline 62.2 & Early Miocene.. & Clay, silty, phosphatic, massive- to thin-bedded, compacted to plastic; moderate $\mathrm{H}_{2} \mathrm{~S}$ odor. \\
\hline 92.9 & & Clay, silty, phosphatic, plastic. \\
\hline \multicolumn{3}{|c|}{ Core hole J-2 (lat $30^{\circ} 21^{\prime}$ N., long $80^{\circ} 20^{\prime}$ W.)-water depth, 42-46 meters } \\
\hline 0 & Post-Miocene _. & $\begin{array}{l}\text { Sand, coarse-grained, moderately sorted, quartz, shelly, unconsolidated; subangular to } \\
\text { subrounded. }\end{array}$ \\
\hline 101.2 & Early Miocene.. & $\begin{array}{l}\text { Clay, silty, massive to faintly laminated, plastic to partly compacted; foraminifers scarce } \\
\text { to abundant. }\end{array}$ \\
\hline $150.6-153.6$ & Late Eocene... & $\begin{array}{l}\text { Ooze, fine-grained, } 30 \text { percent carbonate, biogenic, calcilutaceous, sandy to clayey, massive, } \\
\text { unconsolidated to compacted; foraminifers abundant; pellets abundant; glauconite } \\
\text { common. }\end{array}$ \\
\hline 183.5 & .....do.... & $\begin{array}{l}\text { Limestone, packstone to wackestone; silty matrix, glauconitic, massive, firm to compacted, } \\
\text { oily odor, scattered shell and foraminifer fragments. }\end{array}$ \\
\hline 213.9 & .....do.. & Limestone, biogenic, wackestone, silty, massive, firm to compacted; foraminifers common. \\
\hline 257.6 & & $\begin{array}{l}\text { Limestone, biogenic, calcarenite, medium-grained, glauconitic, carbonaceous, massive, } \\
\text { firm to hard; oily odor; carbonaceous black oily flake; algae; shells. }\end{array}$ \\
\hline 275.8 & .....do... & $\begin{array}{l}\text { Limestone, biogenic, silty packs' one, massive, firm to compacted; slight } \mathrm{H}_{2} \mathrm{~S} \text { odor, glauconitic } \\
\text { lumps of very fine grained aggregates. }\end{array}$ \\
\hline
\end{tabular}


TABLE 1.-Identification of samples from JOIDES core holes-Continued

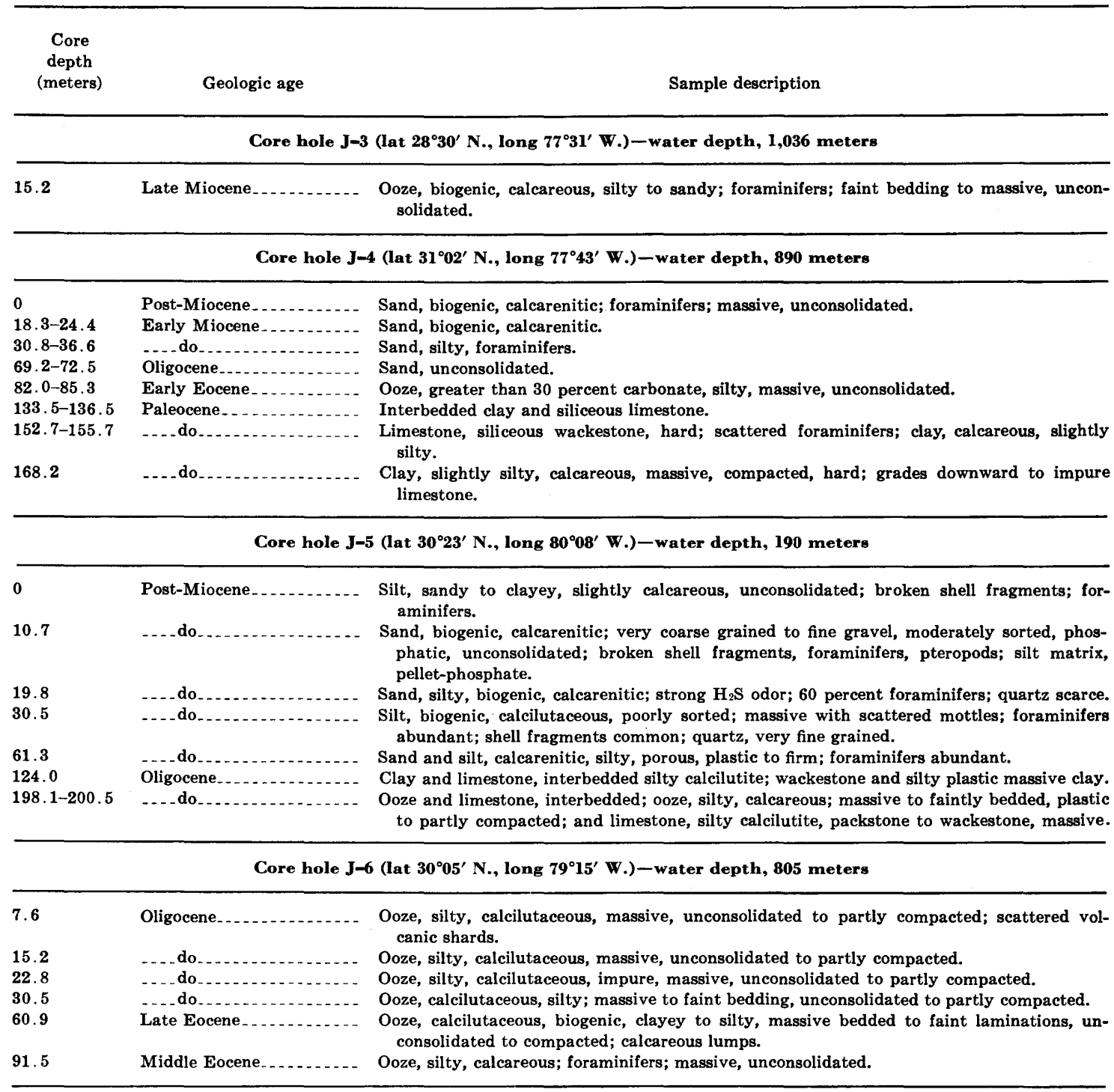

The small quantities of EOM obtained from many of the individual samples made it necessary to combine two or more samples to form a larger sample for analysis. Selection of samples for the composites was restricted to single core sites and guided by depth sequence and lithologic similarity. Compositing resulted in 30 samples which were analyzed by the above procedures. Seven of these 30 samples were omitted from consideration because they were suspected of being contaminated during drilling by lubricating grease such as pipe-joint lubricant. Evidence for contamination consisted of excessive percentages (in excess of 30 percent) of heavy saturated hydrocarbons $\left(\mathrm{C}_{20+}\right)$ in the extract without parallel increases of hydrocarbons in the lower $\left(\mathrm{C}_{12}-\right.$ $\mathrm{C}_{20}$ ) molecular size range. Analytical data for the remaining 23 samples are given in table 2 ; composite samples are indicated by braces.

\section{DISCUSSION}

It may be noted in table 2 that heavy hydrocarbon $\left(\mathrm{C}_{18+}\right)$ concentrations range from 4.0 to $37.5 \mathrm{ppm}$ (parts per million) with a median of $11 \mathrm{ppm}$, which is in contrast to median values of $100 \mathrm{ppm}$ for sediments in general (Gehman, 1962).

If the sediments represented are judged by the criteria of Philippi (1957) and Hunt and Meinert (1958), the small quantities of hydrocarbons in these sediments indicate poor prospects for source rock of petroleum. Samples at $\mathbf{1 8 3 . 5}$ and 257.5 meters from core hole $\mathrm{J}-2$ were reported to have an oily odor (table 1). The hydrocarbon content of the composite sample containing these samples was 4.0 ppm, indicating little or no oil staining.

Heavy hydrocarbon $\left(\mathrm{C}_{18+}\right)$ content, as percent of total organic carbon within ancient sediments, 
TABLE 2.-Analytical data on organic extracts in samples from JOIDES core holes

[Analysts: E. D. Evans and G. M. Williams. F-1 =n-heptane fractions; F-2 = carbon tetrachloride fractions; F-3 = benzene fraction; F-4 = methanol fraction; F-5 = noneluted fraction. See page C2-C3 for the type of organic extract contained in each fraction. EOM = extractable organic material]

\begin{tabular}{|c|c|c|c|c|c|c|c|c|}
\hline \multirow{2}{*}{$\begin{array}{c}\text { Core } \\
\text { depth } \\
\text { (meters) }\end{array}$} & \multirow{2}{*}{$\begin{array}{l}\text { EOM } \\
(\mathbf{p p m})\end{array}$} & \multirow{2}{*}{$\begin{array}{c}\text { Heavy } \\
\text { hydro- } \\
\text { carbons } \\
\left(\mathrm{C}_{18+} \text { ) in }\right. \\
\text { sediment } \\
\text { (ppm) }\end{array}$} & \multicolumn{4}{|c|}{$\begin{array}{l}\text { Silica gel chromatographic fractions } \\
\text { (percent organic extract) }\end{array}$} & \multirow{2}{*}{$\begin{array}{c}\text { Percent } \\
\text { C }_{18+} \\
\text { hydro- } \\
\text { carbons } \\
\text { in } \\
\text { EOM }\end{array}$} & \multirow{2}{*}{$\begin{array}{c}\text { Percent } \\
\mathrm{C}_{12}-\mathrm{C}_{20} \\
\text { in } \\
\text { saturated } \\
\text { hydro- } \\
\text { carbons }\end{array}$} \\
\hline & & & F-1 & F-2 & $\mathbf{F}-\mathbf{3}$ & $F-(4+5)$ & & \\
\hline \multicolumn{9}{|c|}{ Core hole J-1 } \\
\hline $\mathbf{0}$ & 64.0 & 6.3 & 3.3 & $\mathbf{3 . 3}$ & 3.3 & 90.1 & 9.9 & 18.6 \\
\hline 15.2 & 58.0 & 5.6 & 3.2 & 3.2 & 3.2 & 90.4 & 9.6 & 19.6 \\
\hline 22.8 & 253.0 & 15.2 & 2.0 & 2.0 & 2.0 & 94.0 & 6.0 & 38.8 \\
\hline 30.5 & 332.0 & 14.9 & .8 & .8 & 2.9 & 95.5 & 4.5 & 48.2 \\
\hline 62.2 & 296.0 & 25.8 & 2.9 & 2.9 & 2.9 & 91.3 & 8.7 & 44.5 \\
\hline 92.9 & 293.0 & 37.5 & 6.4 & 2.1 & 4.3 & 87.2 & 12.8 & 28.3 \\
\hline \multicolumn{9}{|c|}{ Core hole J-2 } \\
\hline 0 & 10.0 & $\ldots$ & $\ldots$ & $\ldots$ & $\ldots$ & $\ldots$ & $\ldots$ & $\ldots$ \\
\hline 101.2 & 300.0 & 26.1 & 2.9 & 2.9 & 2.9 & 91.3 & 8.7 & 42.6 \\
\hline $150.6-153.6$ & 183.0 & 10.8 & 2.0 & 1.9 & 2.0 & 94.1 & 5.9 & 36.0 \\
\hline $183.5,213.9,257.5,275.8$ & 23.0 & 4.0 & 8.7 & 4.3 & 4.3 & 82.7 & 17.3 & 32.3 \\
\hline \multicolumn{9}{|c|}{ Core hole J-3 } \\
\hline 15.2 & 14.0 & $-\cdots$ & --- & $-\cdots$ & --- & $\cdots$ & $\cdots$ & $-\cdots$ \\
\hline \multicolumn{9}{|c|}{ Core hole J-4 } \\
\hline 0 & 26.0 & --- & $\ldots$ & $\ldots$ & $-\ldots$ & $-\ldots$ & $-\cdots$ & $\ldots$ \\
\hline $18.3-24.4$ & 20.0 & $\ldots$ & $\ldots$ & $\ldots$ & $\ldots$ & $-\cdots$ & --- & $\ldots$ \\
\hline $30.8-36.6$ & $\mathbf{3 1 . 0}$ & $\ldots$ & --- & $\ldots$ & -- & $\ldots$ & $-\ldots$ & $\ldots-$ \\
\hline $\begin{array}{l}69.2-72.5 \\
82.0-85.3,133.5-136.5\end{array}$ & 28.0 & $-\cdots$ & --- & $\cdots$ & --- & $\cdots$ & $\cdots$ & $-\cdots$ \\
\hline $152.7-155.7,168.2$ & 47.2 & 10.5 & 14.8 & 3.7 & 3.7 & 77.8 & 22.2 & 34.5 \\
\hline \multicolumn{9}{|c|}{ Core hole J-5 } \\
\hline 0 & 280.0 & 11.7 & 1.4 & 0.7 & 2.1 & 95.8 & 4.2 & 20.7 \\
\hline $10.7,19.8,30.5$ & 52.0 & 9.1 & 11.8 & 2.9 & 2.9 & 82.4 & 17.6 & 17.7 \\
\hline 61.3 & 126.0 & 11.6 & 5.3 & 1.3 & 2.6 & 90.8 & 9.2 & 25.7 \\
\hline 124.0 & 255.0 & 22.9 & 4.5 & 1.5 & 3.0 & 91.0 & 9.0 & 29.9 \\
\hline $198.1-200.5$ & 142.0 & 5.5 & 1.3 & 1.3 & 1.3 & 96.1 & 3.9 & 39.4 \\
\hline \multicolumn{9}{|c|}{ Core hole J-6 } \\
\hline $7.6,15.2,22.8,30.5$ & 49.5 & 11.1 & 16.1 & 3.2 & 3.2 & 77.5 & 22.5 & 22.7 \\
\hline $60.9,91.5$ & 22.5 & 7.5 & 16.7 & 8.3 & 8.3 & 66.7 & 33.3 & 18.5 \\
\hline
\end{tabular}

is generally much higher in carbonates than in shales and clays (Hunt, 1961; Gehman, 1962). This relation suggests that clay and carbonate provinces should be separated when considering hydrocarbon and organic-matter content of sediments.

Carbonate and total organic carbon data were obtained by Hülsemann (1968) on splits (fractions) of the samples described in table 1. Hülsemann's carbonate data expressed as percent $\mathrm{CaCO}_{3}$ (table 3) indicate two general groupings of the samples.

The samples containing more than 77 percent carbonate minerals form a group in contrast to those containing less than 70 percent carbonate. Samples from the Blake Plateau (J-3, J-4, J-6, fig. 1 and table 3) were predominantly in the high-carbonate group, whereas samples from sites J-1 and J-5 were predominantly in the low-carbonate group.

It may be noted from table 3 that samples from greater depths beneath the shelf and slope belong to the high-carbonate group.

The average heavy hydrocarbon $\left(\mathrm{C}_{18+}\right)$ content, as percent of total organic carbon, for the highcarbonate samples was greater than that for the low-carbonate samples as anticipated (table 3). 
TABLE 3.-Organic carbon, hydrocarbon, calcium carbonate, and EOM contents in samples from JOIDES core holes

[Organic carbon and calcium carbonate contents from Húlsemann, 1968, table 1]

\begin{tabular}{|c|c|c|c|c|}
\hline $\begin{array}{c}\text { Core } \\
\text { depth } \\
\text { (meters) }\end{array}$ & $\begin{array}{c}\text { Organic } \\
\text { carbon } \\
\text { (percent } \\
\text { dry } \\
\text { weight) }\end{array}$ & $\begin{array}{c}\text { Heavy } \\
\text { hydro- } \\
\text { carbons } \\
\left(\mathrm{C}_{18+}\right) \\
\text { as percent } \\
\text { of organic } \\
\text { carbon }\end{array}$ & $\begin{array}{c}\text { Calcium } \\
\text { carbonate } \\
\left(\mathrm{CaCO}_{3}\right) \\
\text { in percent } \\
\text { dry } \\
\text { weight }\end{array}$ & $\begin{array}{c}\text { EOM } \\
\text { as percent } \\
\text { of organic } \\
\text { carbon }\end{array}$ \\
\hline \multicolumn{5}{|c|}{ Core hole J-1 } \\
\hline 0 & 0.11 & 0.57 & 19.2 & 5.8 \\
\hline 15.2 & .71 & .08 & 68.2 & .8 \\
\hline 22.8 & 1.03 & .15 & 46.1 & 2.5 \\
\hline 30.5 & .90 & .17 & 2.9 & 3.7 \\
\hline 62.2 & 1.04 & .25 & 20.0 & 2.8 \\
\hline 92.9 & 1.20 & .31 & 59.7 & 2.4 \\
\hline \multicolumn{5}{|c|}{ Core hole J-2 } \\
\hline 101.2 & 1.10 & 0.24 & 62.9 & 2.7 \\
\hline $150.6-153.6$ & 1.20 & .09 & 83.6 & 1.5 \\
\hline $\begin{array}{r}183.5,213.9 \\
257.5,275.8\end{array}$ & 1.30 & .13 & 285.9 & .8 \\
\hline
\end{tabular}

\begin{tabular}{|c|c|c|c|c|}
\hline \multicolumn{5}{|c|}{ Core hole J-3 } \\
\hline 15.2 & 0.04 & $\ldots$ & 87.6 & 3.5 \\
\hline \multicolumn{5}{|c|}{ Core hole J-4 } \\
\hline 0 & 0.11 & . . - & 95.6 & 2.4 \\
\hline $18.3-24.4$ & .11 & - . - & 86.8 & 1.8 \\
\hline $30.8-36.6$ & .21 & . . . & 80.5 & 1.5 \\
\hline $69.2-72.5$ & .09 & $\ldots$ & 88.7 & 3.1 \\
\hline $\begin{array}{l}82.0-85.3, \\
133.5-136.5\end{array}$ & & & & \\
\hline $152.7-155.7,168.2$ & 1.31 & .34 & 255.9 & 1.5 \\
\hline
\end{tabular}

\begin{tabular}{lccrc}
\hline \multicolumn{5}{c}{ Cole hole J-5 } \\
\hline 0 & 0.91 & 0.13 & 65.1 & 3.1 \\
$10.7,19.8,30.5$ & 1.38 & .24 & 269.3 & 1.4 \\
61.3 & .93 & .12 & 60.8 & 1.4 \\
124.0 & 1.18 & .19 & 66.1 & 2.2 \\
$198.1-200.5$ & 1.13 & .05 & 78.1 & 1.3 \\
\hline \multicolumn{5}{c}{ Core hole J-6 } \\
\hline $7.6,15.2,22.8,30.5$ & 10.09 & 1.23 & 289.7 & 5.5 \\
$60.9,91.5$ & 1.05 & 1.50 & 283.8 & 4.5 \\
\hline
\end{tabular}

1 Average organic carbon.

${ }^{2}$ Average carbonate.

However, the quantity of hydrocarbons relative to the amount of organic carbon was very low when compared with ancient rocks in general. Heavy hydrocarbons $\left(\mathrm{C}_{18+}\right)$, as percent of total organic carbon, ranged from 0.05 to 1.50 with an average of 0.6 for the high-carbonate samples and from 0.08 to 0.34 with an average of 0.23 for the low-carbonate samples. These values compare with approximate averages of 11.7 percent for ancient carbonates in general and 4 percent for ancient shales in general (Hunt, 1961). These sparse amounts of hydrocarbons seem even more unusual when it is observed that the total amounts of organic carbon are nearly normal for both the sediments that have a high percentage of carbonate and those that have less carbonate. The average quantity of organic carbon for the high-carbonate samples is 0.33 percent of the dry sediment, which is not far from the average of 0.29 percent reported for ancient carbonates in general (Hunt, 1961; Gehman, 1962). A similar analogy may be drawn for the low-carbonate province which contains an average quantity of 0.81 percent of organic carbon in the dry sediment as compared with a median value near 1.2 percent for shales in general (Hunt, 1961; Gehman, 1962).

The geographic province and the carbonate content were used to group samples that were compared for differences in hydrocarbon content of sediments as a function of depth. Sufficient data were not available for either the Blake Plateau or the shelf and slope to compare shallow and deep samples in the high-carbonate group. However, there were 11 samples in the low-carbonate group from the shelf and continental slope. Five of these samples were from depths less than 25 meters below the ocean floor, three being from the shelf and two from the continental slope. Six of the 11 samples were from depths greater than 25 meters below the ocean floor, four being from the shelf and two from the continental slope. The saturated hydrocarbons with molecular sizes ranging from $\mathrm{C}_{12}$ to $\mathrm{C}_{20}$ averaged 22.1 percent of the total saturated hydrocarbons $\left(\mathrm{C}_{12}-\mathrm{C}_{30}\right)$ for the five samples above 25 meters depth, whereas in the remaining six samples from greater depths, this fraction averaged 36.5 percent. The samples at greater depth thus contain saturated hydrocarbons enriched in the smaller molecular sizes relative to those at shallower depths.

Average values for the heavy hydrocarbons $\left(\mathrm{C}_{18+}\right)$, as percent of total organic carbon, are not significantly different for the two sample groups. This average for samples at depths less than 25 meters below the ocean floor is 0.234 percent, whereas the average for the deeper samples is 0.228 percent.

\section{SUMMARY AND CONCLUSIONS}

Extracts of samples representing corings of Tertiary strata at six sites off the coast of northern Florida and across the Blake Plateau contained very meager quantities of hydrocarbons and other organic material soluble in organic solvents. Heavy hydrocarbon $\left(\mathrm{C}_{18+}\right)$ values ranged from 4.0 to 37.5 ppm with a median of $11 \mathrm{ppm}$. This median compares with a $100 \mathrm{ppm}$ median for sediments in general. The 
small quantities of hydrocarbons do not suggest that these sediments are a source for petroleum.

The $\mathrm{C}_{12}-\mathrm{C}_{20}$ molecular size range averages 22.1 percent of the total saturated hydrocarbons at depths less than 25 meters and 36.5 percent at depths below 25 meters beneath the sea floor in sparse sampling of the low-carbonate sediments on the shelf and slope. This relation indicates a likelihood of finding larger proportions of the lighter hydrocarbons in deeper samples.

\section{REFERENCES}

Baker, D. R., 1962, Organic geochemistry of Cherokee group in southeastern Kansas and northeastern Oklahoma: Am. Assoc. Petroleum Geologists Bull., v. 46, no. 9, p. 16211642 .

Gehman, H. M., Jr., 1962, Organic matter in limestones: Geochim. et Cosmochim. Acta, v. 26, p. 885-897.
Hülsemann, Jobst, 1968, Calcium carbonate, organic carbon, and nitrogen in sediments from drill holes on the continental margin off Florida: U.S. Geol. Survey Prof. Paper 581-B, 10 p.

Hunt, J. M., 1961, Distribution of hydrocarbons in sedimentary rocks, in Symposium on the chemical approaches to the recognition of petroleum source rocks: Geochim. et Cosmochim. Acta, v. 22, p. 37-49.

Hunt, J. M., and Meinert, R. N., 1958, Petroleum prospecting: U.S. Patent 2,854,396.

Joint Oceanographic Institutions' Deep Earth Sampling Program, 1965, Ocean drilling on the continental margin: Science, v. 150 , no. 3697 , p. 709-716.

Philippi, G. T., 1957, Identification of oil source beds by chemical means, in Geología del petróleo: Internat. Geol. Cong., 20th, Mexico, D. F., 1956, Trabajos, sec. 3, p. 25-38.

Schlee, John, and Gerard, Robert, 1965, Cruise report and preliminary core log MV Caldrill I--17 April to 17 May 1965: Joint Oceanog. Inst. Deep Earth Sampling Program Blake Panel Rept., 64 p.

U. S. GOVERNMENT PRINTING OFFICE : 1969 O - 334-790 

. 


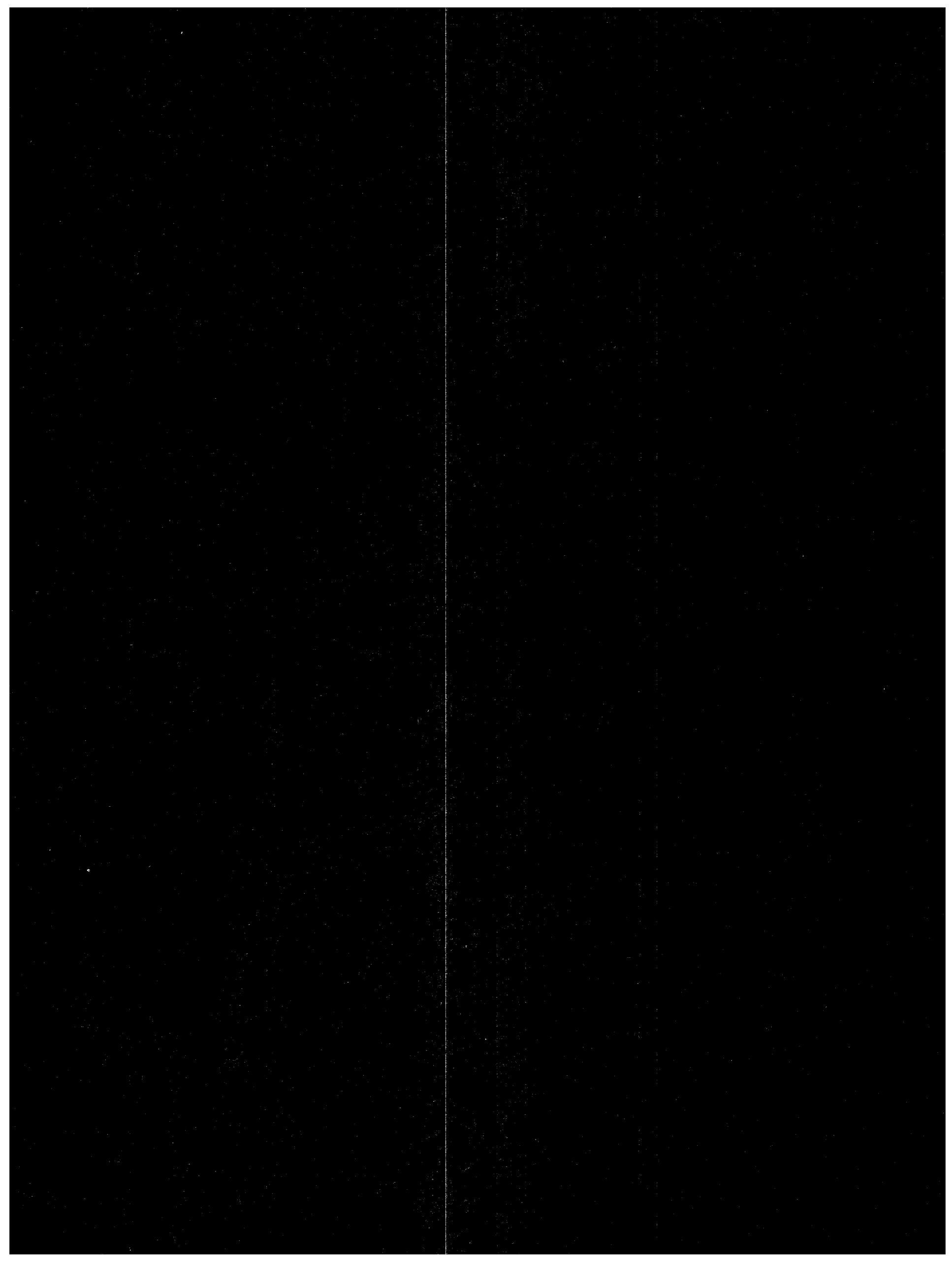




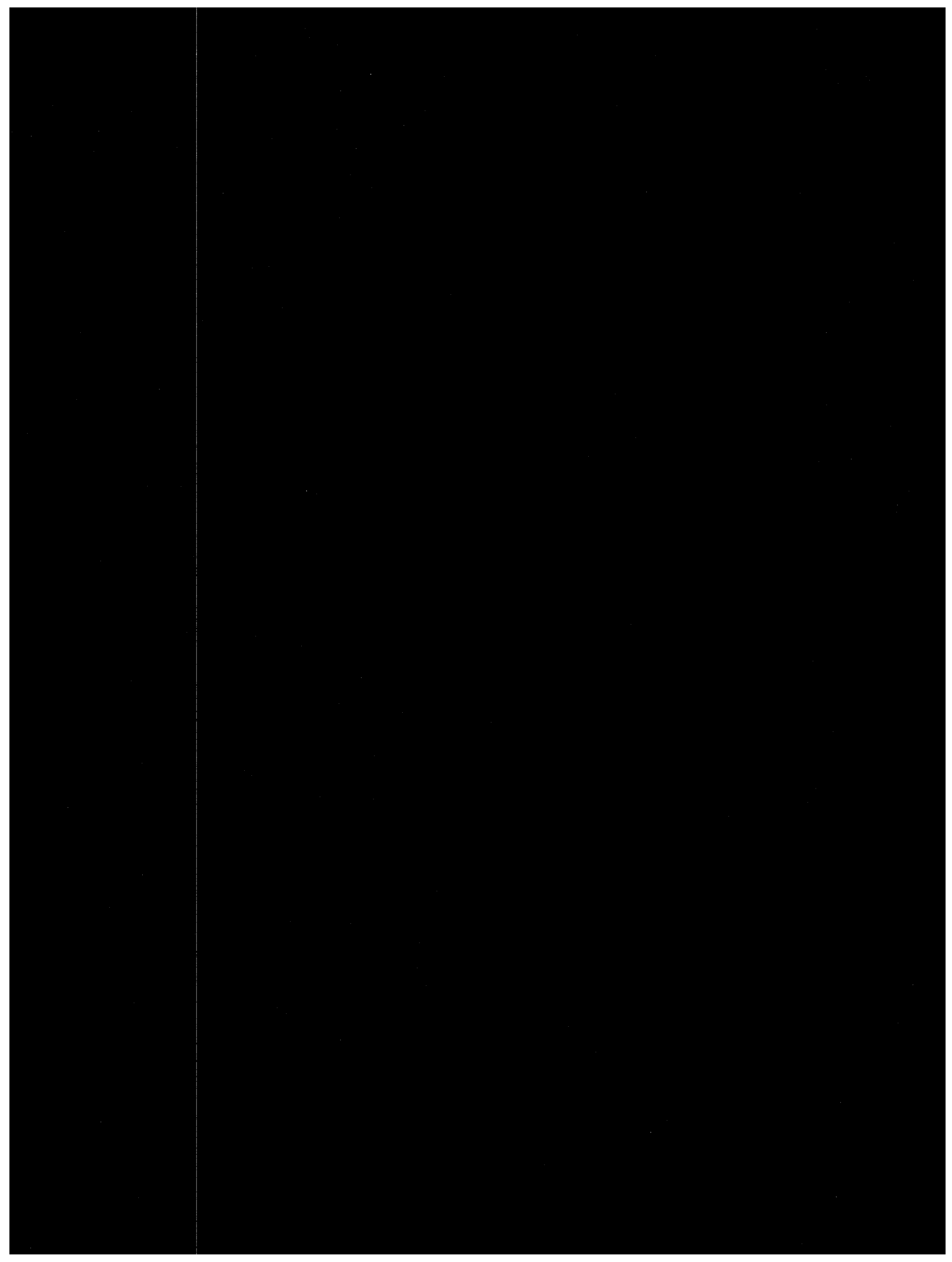

